\title{
The Pathological Features of Leukaemic Cells Infiltrating Renal Interstitium in Chronic Lymphocytic Leukaemia/small Lymphocytic Lymphoma Within 10 Years in a Large Single Chinese Centre
}

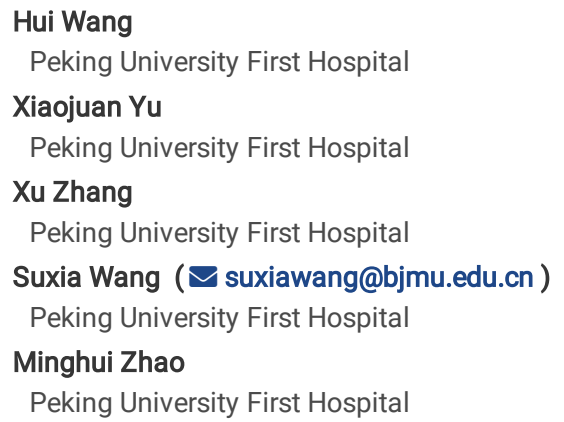

Keywords: Chronic lymphocytic leukemia/Small Lymphocytic Lymphoma (CLL/SLL), infiltrating leukaemic cells, monoclonal immunoglobulin, pathological features, tubulointerstitial injury

Posted Date: January 19th, 2021

DOI: https://doi.org/10.21203/rs.3.rs-147202/v1

License: (c) (1) This work is licensed under a Creative Commons Attribution 4.0 International License. Read Full License 


\section{Abstract}

Background Chronic lymphocytic leukemia/Small Lymphocytic Lymphoma (CLL/SLL) was rare in Asians and patients with CLL/SLL rarely undergo kidney biopsy. Little information is available on the histopathological features and clinical relevance of CLL/SLL tubulointerstitial injury. Hence, we attempted to describe the clinical characteristics, renal pathology and clinical outcome of a well characterized population of CLL/SLL patients with CLL infiltration in renal interstitium from a large single center in China.

Methods Between January 1st, 2010 to September 31st, 2020, 31946 reanl biopsy pathology were performed at Peking University First Hospital and 10 patients with CLL infiltration in renal interstitium were included. Complete clinical data were collected from these 10 patients and the renal specimens were examined by routine light microscopy, immunonuorescence and electron microscopy examination.

Results The extent of infiltrating CLL cells was diverse between different patients, from $10 \%$ to $90 \%$. Five patients presented interstitial infiltration with the percent of infiltrate CLL cells $\geq 50 \%$. Proliferation centers were formed in the renal interstitium of 6 patients $(6 / 10,60 \%)$. Intrestingly, we found three patients $(3 / 10,30 \%)$ expressed monoclonal immunoglobulin in infiltrating CLL cells and special crystal structures were found in these cells in two of the three patients for the first time.

Conclusions The finding confirmed CLL cells infiltrating in renal interstitium can secret monoclonal immunoglobulins directly, indicating that CLL cells in renal interstitium probably directly involved in local lesion injurys by secrecting monoclonal immunoglobulin. This finding will help understanding the mechanism of renal injury with CLL infiltration, thereby improving our current therapeutic efforts.

\section{Background}

Chronic lymphocytic leukemia/Small Lymphocytic Lymphoma (CLL/SLL), the most common adult leukemia in the Western world [1], however, infrequent in Asians. It is characterized by the clonal expansion of CD $5+C D 23+B$ cells in blood, marrow, and secondary lymphoid tissues. Extramedullary/Extranodal manifestations of CLL/SLL are rare. Most often involved organs are the skin and central nervous system. Kidneys were rarely involved [2-3]. A study from the Mayo Clinic found a 7.5\% incidence of renal insufficiency at the time of CLL/SLL diagnosis in a cohort of over 4000 CLL/SLL patients. Importantly, the presence of kidney disease is independently associated with adverse patient outcomes in CLL/SLL [4], which emphasized the importance of detailed exploration of the mechanism of renal insufficiency in CLL/SLL.

In renal complications of CLL/SLL, the mechanism of renal insufficiency in such patients varies. Besides glomerular injury which including direct glomerular deposition of monoclonal protein, cryoglobulins, and immune-complexes [4-5], renal tubulointerstitial injury was also an important mechanism. Previous case reports and studies mainly focused on glomerular injury associated with CLL/SLL. However, little information is available on the histopathological features and clinical relevance of CLL/SLL tubulointerstitial injury. Up to date, literatures related to CLL infiltration of the kidney were either single patient case reports or small case series [4-5, 6-10], with the largest report including 6 patients [4]. In these literatures, histopathological features of CLL cells infiltrating in renal interstitium were not detailed described and the mechanism of renal injury with CLL infiltration was not studied.

In this study, we attempted to describe the clinical characteristics, renal pathology and clinical outcome of a well characterized population of CLL/SLL patients with CLL infiltration in renal interstitium from a large single centre at Peking University First Hospital in China. We detailed explored histopathological changes of the tubular and interstitium and the pathogenesis of CLL cells infiltrating in renal interstitium.

\section{Methods}

\section{Patients}

Between January 1st, 2010 to September 31st, 2020, 31946 reanl biopsy pathology were performed at Peking University First Hospital. Finally, after screening of the renal pathology database, 10 patients with CLL infiltration in renal interstitium were included. CLL/SLL was diagnosed according to the WHO classification [11]. The diagnosis of CLL requires the presence of at least $5 \times 10^{9} \mathrm{~B}$ lymphocytes/L in the peripheral blood over $>3$ months, with evidence of monoclonality (CD5, CD19, CD20, CD23). CLL is distinguishable from SLL by its leukemic appearance. The definition of SLL requires a histological analysis of lymph node biopsy. An ascertained CLL/SLL of all 10 patients were diagnosed before or at the time of the kidney biopsy. No plasma cell neoplasms were detected.

Informed consent was obtained from each patient. The research was in compliance with the declaration of Helsinki and approved by the ethic committee of Peking University First Hospital.

\section{Clinical and laboratory assessment during follow-up}

Baseline clinical data, including age, sex, medical history, CLL clinic course, CLL involved organs, proteinuria, hematuria, serum creatinine, complete blood test, serum/urine immunofixation electrophoresis, treatment, were obtained from clinical records. eGFR was calculated using the Epidemiology Collaboration equation. Patients were followed up in the outpatient clinic or by telephone.

\section{Renal histopathology assessment}

Renal biopsy was examined by standard direct immunofluorescence, light microscopy and electron microscopy. For light microscopy, biopsy specimens were stained with hematoxylin-eosin, periodic acid Schiff, Masson trichrome, and Jones methenamine silver and massone trichrome staining. For immunofluorescence, 3-micro cryostat sections were stained with polyclonal fluorescein isothiocyanate-conjugated antibodies to IgG, IgM, IgA, C3, C1 q, kappa 
light chain, lambda light chain and IgG subclasses. Electron microscopy was performed as per clinical routine. Immunohistochemical staining for CD3, CD5, CD20, CD23, Cyclin D1, CD43, TdT, CD10, BCL6 were done on renal biopsy to assess CLL/SLL involvement. Two pathologists specializing in evaluation of renal pathology evaluated renal biopsies separately. All cases were also reviewed by hematopathologists specializing in review of lymphoid malignancy. Differences in diagnosis between the two pathologists were resolved by re-reviewing the biopsies to reach a consensus.

\section{Immunoelectron microscopy (IEM)}

Immuno-gold labeling was further performed according to the methods described by previous studies [12]. The 80-nm-thick resin-embedded sections were attached on the surface of a carbon-coated support film grid and blocked with $2 \%$ bovine serum albumin in $0.01 \mathrm{M}$ phosphate buffer saline, pH7.4, saline for 5 min at $37^{\circ} \mathrm{C}$, followed by incubation overnight at $4{ }^{\circ} \mathrm{C}$, using an extensive panel of antibodies reactive with polyclonal rabbit anti-human kappa and lambda light chain (1:1000; Dako, Carpenteria, CA), monoclonal mouse anti-human IgG1, IgG2, IgG3, IgG4 (1:100; SouthernBiotech, Birmingham, AL). Then, after incubation with a gold-conjugated secondary antibody (colloid gold particle in a diameter of $10 \mathrm{~nm}$ ) for $1 \mathrm{~h}$, the grid was ready for observation using the transmission electron microscope. Negative controls were prepared by omitting the primary antibody.

\section{Statistical analysis}

Statistical software SPSS 13.0 (SPSS, Chicago, IL, USA) was used. Descriptive statistics of baseline characteristics were calculated. Continuous data were expressed as mean \pm s.d, or median with range. Categorical variables were presented as proportions.

\section{Results}

\section{Demographic and baseline clinical data}

The clinical features at biopsy are presented in Table 1.5 male (50\%) and 5 female (50\%) were enrolled. The mean age was $64 \pm 4.9$ (range $58-73$ ) years old. The CLL/SLL had been diagnosed before kidney biopsy in 5/10 cases, with a mean interval of 23.8 months (range 2-60months). Four patients were biopsied for acute kidney disease, two for acute kidney injury and four for proteinuria. The mean peak serum creatinine before renal biopsy was $276.6 \pm 192.3 \mu \mathrm{mol} / \mathrm{L}$ (range: $95-616 \mu \mathrm{mol} / \mathrm{L}$ ). The median proteinuria was $3.5 \mathrm{~g} / 24 \mathrm{hr}$ (range: $0.48-12.8$ ) with a mean serum albumin of $33.6 \pm 9.1 \mathrm{~g} / \mathrm{L}$. Seven patients $(70 \%)$ had microscopy hematuria. All patients had bone marrow biopsy, and eight patients (80\%) showed CLL/SLL bone marrow infiltration. Nine patients ( $90 \%)$ had multiple enlarged lymph nodes, and all of them had lymph node biopsy with the definition of SLL. One patients had splenomegaly. Six patients (60\%) had monoclonal immunoglobulins, including 3 patients with $\lg \mathrm{MK}_{\mathrm{K}} 2$ patients with $\lg \mathrm{G}_{\mathrm{K}}$ and 1 patient with $\lg \mathrm{M} \lambda$.

\section{Renal biopsy findings}

Tables 2 summarize the pathology characteristics of the kidney biopsy. All of these patients presented varying degrees of CLL cells infiltration in renal interstitium, composed mainly of small mature lymphocytes, with small hyperchromatic nuclei, expanding the interstitium at the expense of the tubular structures, the peritubular capillaries, and less frequently the glomeruli (Figure 1). Immunohistochemistry revealed monotypic lymphocytes (CD20+, CD5+, CD23+, CyclinD1-, CD10-, CD138-, CD68-) (Figure 1). The extent of infiltrating CLL cells was diverse between different patients, from 10\% to 90\%. Five patients presented interstitial infiltration with the percent of infiltrate CLL cells $\geq 50 \%$.

Proliferation centers were found in 6 patients (60\%), which are concentrations of prolymphocytes and paraimmunoblasts. This was a spectrum of larger cells with more dispersed chromatin, conspicuous nucleoli, and more abundant cytoplasm than small mature lymphocytes (Figure 1). Of the 6 patients, two patients (Case 6 and Case10) showed monoclonal immunoglobulin expressions in renal interstitium by immunofluorescence (IgG1k for case6 and IgMk for case10), which were identical to that of the serum immunoglobulin paraprotein. Interestingly, special crystal structures were found in infiltrating CLL cells in one patient (Case 6) and fuzzy filament structure can be seen in these crystal structures (Figure 2). The special structures formed in infiltrating CLL cells was different from those formed in glomerulus which were characterized by 40-nm diameter microtubules (Figure 2). Notably, IgG1k expression was detected in these crystals by immunoelectron microscopy (Figure 3). In another patient (Case 2) whose immunofluorescence showed no specific interstitial deposit, rhombic crystal formation was also found in infiltrating CLL cells and monoclonal $\lambda$ was expressed in these cystals by immunoelectron microscopy (Figure 4). Totally, three patients (30\%) expressed monoclonal immunoglobulin in infiltrating CLL cells. In addition, non-necrotic epithelioid granulomas were found in one patient (Case 5). Light microscopy revealed interstitial gigantocellular granulomas, surrounded by lymphocytes (Figure 1). Periodic Acid Schiff, Ziehl and Grocott stainings revealed no microorganism. Immunofluorescence showed no specific interstitial deposit.

Eight patients were accompanied with glomerular diseases as well. Membranoproliferative glomerulonephritis (MPGN) was present in 3 patients (Case 4, 6 and 10). The immunofluorescence showed monoclonal immunoglobulin expression in glomeruli and large subendothelial deposits characterized by 40 -nm diameter microtubule formation. 2 patients showed endocapillary proliferative glomerulonephritis (Case 3 and 7). Bright C3 deposition were detected by immunofluorescence. The ultrastructural findings of massive hump-like subepithelial deposits indicated bacterial infection-associated glomerulonephritis in these two patients. In addtion, 1 patient (Case 1) showd phospholipase A2 receptor negative membranous nephropathy. 1 showd thrombotic microangiopathy (Case 8). 1 showd obesity associated glomerular hypertrophy (Case 9).

\section{Treatment and prognosis}

Nine patients had follow-up information. The mean post-biopsy follow-up was 26.1 months (range 2-56 months). As shown in table 1, four patients received chemotherapy. One patient (Case 5) was treated with 2 cycles of cyclophosphamide, doxorubicin, vincristine and prednisone (CHOP) before kidney biopsy, and after the renal biopsy, she was treated with ibrutinib. Her renal function achieved partial recovery and CLL/SLL showed no sign of progression. Two patients (Case3 and 6) were treated with chemotherapy after kidney biopsy, including cyclophosphamide, vincristine, and prednisone(COP) followed by rituximab and 
ibrutinib, and their CLL/SLL were stable. One patient (Case 4) was treated with 1 cycle of rituximab, fludarabine and cyclophosphamide (RFC) and discontinued due to patient's reluctance of chemotherapy, and her renal function improved with CLL/SLL stable for a 31 months follow up time. Five patients don't receive chemotherapy. one patients (Case 1) was treated with interferon for 2 months and discontinued after kidney biopsy. Then he was treated with cyclophosphamide and cyclosporine for membranous nephropathy but with no remission. Patient 7 was only treated with prednisone and her renal function improved. Patient 8 was treated with plasma exchange for thrombotic microangiopathy which showed hematologic complete remission and recovery of acute kidney injury for 2 episodes. Chemotherapy was suggested for patient 2 and 9 but they refused.

\section{Discussion}

CLL/SLL is extremely rare in Asians compared with persons of predominately European descent [1]. Unlike plasma cell dyscrasias, in which kidney biopsy is routinely performed to evaluate unexplained renal insufficiency [13], patients with CLL/SLL rarely undergo kidney biopsy due to the fact that CLL/SLL usually follows an indolent course. In the series from Mayo Clinic [4], of all the CLL/SLL patients studied, only $1.2 \%$ of patients underwent kidney biopsy. The low rate of kidney biopsy is a limiting factor in our understanding of CLL/SLL associated kidney disease. Here, we attempted to better describe the pathological features of CLL/SLL patients with CLL infiltration in renal interstitium in Chinese patients. Particularly, we also showed CLL cells in renal interstitium expressed monoclonal immunoglobulin with crystals formation for the first time. This pathological feature might provide useful information in the understanding of the mechanism of renal injury with CLL cells infiltration.

In CLL/SLL, the prevalence rates of hypogammaglobulinemia and monoclonal paraprotein in serum are $25 \%$ and $11 \%$ [14-15], respectively. The presence of serum paraprotein has been showed a worse prognosis of CLL/SLL patients [16-17]. In our study, 30\% of patients expressed monoclonal immunoglobulin in CLL cells infiltrating in renal interstitium, which indicating CLL cells probably directly involved in local lesion injurys by secrecting monoclonal protein. Up to date, the mechanism of renal injury with CLL infiltration is not clearly established but has been hypothesized to involve tubular/microvascular compression causing intrarenal obstruction in addition to an infiltration-associated inflammatory/cytokine response [3-5]. For example, diffuse infiltration likely compresses the renal tubules and microvasculature, resulting in intrarenal obstruction and ischemia. Alternatively, cytokines such as IL- 1, IL-6, TNF-a, and TGF- $\beta$, secreted directly by the lymphoma cells, may lead to tubular injury and interstitial fibrosis [18]. Our study indicated that the CLL cells infiltrating in kidney interstitium directly secreted the monoclonal protein. Because the presence of excess free-light chains with crystals formation was sufficient to cause injury to renal proximal tubular cells such as light chain proximal tubulopathy (LCPT) [19], the injury of monoclonal immunoglobulin secreted by CLL cells in kidney interstitium should be assessed.

The occurrence of secreting CLL cells is related either to the development of CLL cells in situ or to the infiltration from CLL cells in the blood. Due to CLL cells in the blood appear to be predominantly resting lymphocytes in G0 [20], focal aggregates of different-sized lymphocytes in the local lymphoid tissue are presumably where leukemia cells proliferate. CLL cell proliferation occurs in local sites termed proliferation centers or pseudofollicles [21]. Interactions between CLL and accessory cells within proliferation centers are critical for providing growth and survival signals to CLL B cells, inducing their proliferation, differentiate either to an antibody-secreting cell or a memory cell, or to remain a nonsecreting blast [22]. In our study, proliferation centers were found in $60 \%$ of patients with CLL infiltration in kidney interstitium, which indicated the kidney microenvironment plays a central role in the pathogenesis of CLL. Growing evidence suggests that different types of stromal cells, such as monocyte-derived nurselike cells, mesenchymal stromal cells and follicular dendritic cells protect CLL cells in coculture and are an integral part of the CLL microenvironment [21-25] Recently, pathways deliver critical survival and drug-resistance signals in the interactions that occur between CLL cells and their microenvironments has gained increasing attention in hemato-oncology, such as CD44, CXCL12,CXCL13,TNF family member BAFF [23, 26-28], and et al. Our study indicated that kidney was most likely another site of minimal residual disease and the source of relapses in patients with CLL. More therapeutic efforts may be put on the inhibition of CLL cell proliferation in kidney interstitium in further, because the presence of excess monoclonal protein with crystals formation was sufficient to cause injury to renal tissues.

This study had some limitations. First, this was a retrospective study. Because more attention were paid to glomeruli in earlier years, we can not exclued the possibility that monoclonal immunoglobulin may be missed when interpretating the immunofluorescence stains in kidney interstitium. Second, the clinicopathological relationship of proliferation center in kidney interstitium or even monoclonal immunoglobulin expression in CLL cells is still unclear due to the limited sample size. A larger number of multicenter research will be needed in the further.

\section{Conclusions}

In summary, we attempted to better describe the pathological features of CLL/SLL patients with CLL infiltration in renal interstitium in Chinese patients. It is noteworthy that monoclonal immunoglobulin expression were dectected in CLL cells infiltrating renal interstitium for the first time. The finding confirmed CLL cells in renal interstitium can secret monoclonal immunoglobulins directly, indicating these cells probably directly involved in local lesion injurys by secrecting monoclonal immunoglobulin. This will help understanding the mechanism of renal injury with CLL infiltration, thereby improving our current therapeutic efforts.

\section{Abbreviations}

CLL

Chronic lymphocytic leukemia; SLL:Small Lymphocytic Lymphoma; MPGN:Membranoproliferative glomerulonephritis; CHOP:cyclophosphamide, doxorubicin, vincristine and prednisone; COP:cyclophosphamide, vincristine, and prednisone; RFC:rituximab, fludarabine and cyclophosphamide; LCPT:light chain proximal tubulopathy.

\section{Declarations}


Ethics approval and consent to participate

The research was in compliance with the declaration of Helsinki and approved by the ethic committee of Peking University First Hospital.

\section{Informed consent statement}

All patients have signed an informed consent form on inclusion and at each follow-up assessment.

\section{Consent for publication}

Written informed consent was obtained from the patient for publication of the case report and any accompanying images.

\section{Availability of data and materials}

All data generated or analysed during this study are included in this published article.

\section{Competing interests}

All authors declare no conflict of interest.

\section{Funding}

This research was supported by grants from National Natural Science Foundation of China (No. 81470956). The funder had no role in conducting the study. The authors conducted this study independently.

\section{Authors' Contributions}

XiaoJuan Yu and Minghui Zhao contributed to patient diagnosis, management and clinical data analysis. Hui Wang, Xu Zhang and Suxia Wang contributed to patient pathological diagnosis, took and edit pathological pictures. Hui Wang and Suxia Wang wrote manuscript drafting, contributed to data analysis and interpretation. Suxia Wang and Minghui Zhao contributed to final review of manuscript.

\section{Acknowledgements}

Not Applicable.

\section{References}

1. Yang SM, Li JY, Gale RP, Huang XJ. The Mystery of Chronic Lymphocytic Leukemia (CLL): Why Is It Absent in Asians and What Does This Tell Us About Etiology, Pathogenesis and Biology? Blood Rev. 2015; 29: 205-213.

2. Hallek, M. Chronic lymphocytic leukemia: 2015 update on diagnosis, risk stratification, and treatment. Am J Hematol. 2015; 90: 446-460.

3. Wanchoo R, Ramirez CB, Barrientos J and Jhaveri KD. Renal involvement in chronic lymphocytic leukemia.Clinical Kidney Journal. 2018; 11: 670-680.

4. Strati P, Nasr SH, Leung N et al. Renal complications in chronic lymphocytic leukemia and monoclonal B-cell lymphocytosis: the Mayo Clinic experience. Haematologica. 2015; 100: 1180-1188.

5. Poitou-Verkinder AL, Francois A, Drieux F et al. Chronic Lymphocytic Leukemia/Small Lymphocytic Lymphoma: A 25-Year Multicenter Experience. PLOS ONE. 2015; 510: e0119156. https://doi:10.1371/journal.pone.0119156.

6. Dipesh Uprety, Alan Peterson, Binay Kumar Shah. Renal failure secondary to leukemic infiltration of kidneys in CLL-a case report and review of literature. Ann Hematol.2013; 92:271-273.

7. J K Phillips, P S Bass, G Majumdar, D R Davies, N F Jones, T C Pearson. Renal failure caused by leukaemic infiltration in chronic lymphocytic leukaemia. J Clin Pathol. 1993; 46:1131-1133.

8. FERREIRA AC, BRUM S, CARVALHO D, et al. Renal dysfunction due to leukemic infiltration of kidneys in a case of chronic lymphocytic leukemia. Hemodialysis International. 2010; 14:87-90.

9. Kamat AV, Goldsmith D, Donnell PO, Walt JVD, Robert Carr R. Renal Failure with Granulomatous Interstitial Nephritis and Diffuse Leukemic Renal Infiltration in Chronic Lymphocytic Leukemia. Renal Failure. 2007; 29:763-765.

10. Kiewe P, Tepel M, Loddenkemper $\mathrm{C}$ et al. Extensive leukemic kidney infiltration with membranoproliferative glomerulonephritis in a patient with B-cell chronic lymphocytic leukemia.Ann Hematol. 2007; 86:691-692.

11. Swerdlow SH, Campo E, Pileri SA, et al. The 2016 revision of the World Health Organization classification of lymphoid neoplasms. Blood. 2016; 127: 2375-2390.

12. Li DY, Liu D, Wang SX, et al. Renal leukocyte chemotactic factor 2 (ALECT2)-associated amyloidosis in Chinese patients. Amyloid. 2020; 27:134-141.

13. Fermand JP, Bridoux F, Kyle RA et al. How I treat monoclonal gammopathy of renal significance (MGRS). Blood. 2013; 122:3583-3590.

14. Parikh SA, Leis JF, Chaffee KG et al. Hypogammaglobulinemia in newly diagnosed chroniclymphocytic leukemia: natural history, clinical correlates, and outcomes. Cancer. 2015; 121:2883-2891.

15. Martin WR. Abraham T. Shanafelt RJ et al. Serum-free light chain-a new biomarker for patients with B-cell non-Hodgkin lymphoma and chronic lymphocytic leukemia. Transl Res. 2007; 149:231-235. 
16. Rizzo DJ, Chauzeix F, Trimoreau JB et al. IgM peak independently predicts treatment-free survival in chronic lymphocytic leukemia and correlates with accumulation of adverse oncogenetic events. Leukemia. 2015; 29:337-345.

17. W Xu, YH Wang, L Fan et al. Prognostic significance of serum immunoglobulin paraprotein in patients with chronic lymphocytic leukemia. Leukemia Research. 2011; 35:1060-1065.

18. Lommatzsch SE, Bellizzi AM, Cathro HP, Rosner MH. Acute renal failure caused by renal infiltration by hematolymphoid malignancy. Ann Diagn Pathol.2006; 10: 230-234.

19. Larsen CP, Bell JM, Harris AA, Messias NC, Wang YH, Walker PD. The morphologic spectrum and clinical significance of light chain proximal tubulopathy with and without crystal formation. Modern Pathology. 2011; 24:1462-1469.

20. Zhang SP and Kipps TJ. The Pathogenesis of Chronic Lymphocytic Leukemia. Annu Rev Pathol. 2014; 9:103-118.

21. Chang JC, Harrington AM, Olteanu H, VanTuinen P, Kroft SH. Proliferation centers in bone marrows involved by chronic lymphocytic leukemia/small lymphocytic lymphoma: a clinicopathologic analysis. Annals of Diagnostic Pathology. 2016; 25: 15-19.

22. Burger JA, Ghia P, Rosenwald A, Cappio FC. The microenvironment in mature B-cell malignancies: a target for new treatment strategies. Blood. 2009; 114 : 3367-3375.

23. Burger JA, Tsukada N, Burger M, Zvaifler NJ, Dell'Aquila M, Kipps TJBlood-derived nurse-like cells protect chronic lymphocytic leukemia B cells from spontaneous apoptosis through stromal cellderived factor-1. Blood. 2000; 96:2655-2663.

24. Lagneaux L, Delforge A, Bron D, De Bruyn C, Stryckmans P. Chronic lymphocytic leukemic B cells but not normal B cells are rescued from apoptosis by contact with normal bone marrow stromal cells. Blood. 1998; 91:2387-2396.

25. Pedersen IM, Kitada S, Leoni LM et al. Protection of CLL B cells by a follicular dendritic cell line is dependent on induction of Mcl-1. Blood. 2002; 100:1795-1801.

26. Zhang S, Wu CCN, Fecteau JF et al. Targeting chronic lymphocytic leukemia cells with a humanized monoclonal antibody specific for CD44. Proc Natl Acad Sci. 2013; 110:6127-6132.

27. Burger JA. Chemokines and chemokine receptors in chronic lymphocytic leukemia (CLL): from understanding the basics towards therapeutic targeting. Semin Cancer Biol. 2010; 20:424-430.

28. Herishanu Y, Pérez-Galán P, Liu D et al. The lymph node microenvironment promotes B cell receptor signaling, NF-kB activation, and tumor proliferation in chronic lymphocytic leukemia. Blood. 2011; 117:563-574.

\section{Tables}

Table 1 The clinical features of CLL/SLL patients at kidney biopsy

\begin{tabular}{|c|c|c|c|c|c|c|c|c|c|c|c|c|c|}
\hline Case & Age/sex & Time & Scr & UTP & Mlg & Cryo & C3 & C4 & ER-IO & Treatment & $\begin{array}{l}\text { F. } \\
\text { time }\end{array}$ & Renal outcome & CLL/SLL \\
\hline 1 & $67 / M$ & 2 & 118 & 10.35 & $\lg M \lambda$ & Trace & $0.57 \downarrow$ & 0.12 & LN & CYC, CsA & 56 & $\begin{array}{l}\text { Not recovery (Scr } \\
159)\end{array}$ & Stable \\
\hline 2 & $66 / M$ & 0 & 616 & 0.80 & Negative & Trace & 0.63 & 0.26 & $\begin{array}{l}\mathrm{LN}, \\
\mathrm{BM}\end{array}$ & Supportive & 52 & $\begin{array}{l}\text { ESRD (never } \\
\text { recovered) }\end{array}$ & Stable \\
\hline 3 & $58 / F$ & 0 & 95 & 1.15 & $\lg \mathrm{GK}_{\mathrm{K}}$ & Negative & 0.92 & 0.21 & BM & $\begin{array}{l}\text { COP, } \\
\text { Rituximab } \\
\text { Ibrutinib }\end{array}$ & 32 & $\begin{array}{l}\text { completely } \\
\text { recovery (Scr 100, } \\
\text { UTP } 0.22 \text { ) }\end{array}$ & Improved \\
\hline 4 & $58 / F$ & 0 & 174 & 0.48 & $\lg M k$ & Negative & $0.48 \downarrow$ & $0.05 \downarrow$ & $\mathrm{LN}, \mathrm{BM}$ & RFC & 31 & $\begin{array}{l}\text { completely } \\
\text { recovery(Scr 79, } \\
\text { UTP negative) }\end{array}$ & Stable \\
\hline 5 & $66 / F$ & 60 & 570 & 0.87 & Negative & NA & 0.72 & 0.34 & $\begin{array}{l}\text { LN, } \\
\text { Spleen } \\
\text { BM }\end{array}$ & $\begin{array}{l}\text { CHOP, } \\
\text { Ibrutinib }\end{array}$ & 15 & $\begin{array}{l}\text { Partial recovery } \\
\text { (Scr 330) }\end{array}$ & Stable \\
\hline 6 & $62 / \mathrm{M}$ & 36 & 118 & 4.27 & $\lg G_{K}$ & $\lg \mathrm{GK}_{\mathrm{K}}$ & $0.57 \downarrow$ & $0.09 \downarrow$ & LN,BM & $\begin{array}{l}\text { COP, } \\
\text { lbrutinib }\end{array}$ & 8 & $\begin{array}{l}\text { completely } \\
\text { recovery (Scr 108, } \\
\text { UTP 1.2) }\end{array}$ & Satable \\
\hline 7 & $68 / F$ & 18 & 456 & 2.17 & Negative & NA & 0.81 & 0.16 & LN, & Prednisone & 6 & $\begin{array}{l}\text { Partial recovery } \\
\text { (Scr 150) }\end{array}$ & Improved \\
\hline 8 & $59 / F$ & 0 & 377 & 0.59 & $\operatorname{lgMk}$ & Type II & $0.46 \downarrow$ & $0.02 \downarrow$ & LN,BM & $\begin{array}{l}\text { PE for } \\
\text { TMA }\end{array}$ & 33 & $\begin{array}{l}\text { Partial recovery } \\
\text { (Scr 197) }\end{array}$ & Progressed \\
\hline 9 & $73 / \mathrm{M}$ & 3 & 161 & 1.44 & Negative & Negative & 0.76 & 0.20 & BM & Supportive & 2 & $\begin{array}{l}\text { Not recovery (Scr } \\
154)\end{array}$ & Stable \\
\hline 10 & $67 / M$ & 0 & 221 & 12.8 & $\lg \mathrm{Mk}$ & $\lg M \kappa$ & $0.244 \downarrow$ & $0.06 \downarrow$ & LN,BM & In hospital & - & - & - \\
\hline
\end{tabular}

Notes: Time: time from diagnosis of CLL/SLL to renal biopsy(month); Scr: peak serum creatinine before renal biopsy( $\mu \mathrm{mol} / \mathrm{L})$ 
Abbreviations: UTP: urine total protein; Mlg: monoclonal immunoglobulin deteremined by serum/urine immunofixation electrophoresis; Cryo:

cryoglobulinemia; ER-IO: extra-renal involved organs; F.time: follow up time (months); LN: lymph node; BM: bone marrow; CYC: cyclophosphamide; CsA: cyclosporine; ESRD: end stage renal disease; COP: cyclophosphamide, vincristine, and prednisone; RFC: rituximab, fludarabine and cyclophosphamide; CHOP: cyclophosphamide, doxorubicin, vincristine and prednisone; PE: plasma exchange; TMA: thrombotic microangiopathy

Table 2 The the kidney biopsy pathology characteristics of the CLL/SLL patients

\begin{tabular}{|c|c|c|c|c|c|c|c|}
\hline & Glomerular & & & Interstitium & & & \\
\hline Case & Light microscopy & Immunofluores-cence & $\begin{array}{l}\text { Electron } \\
\text { microscopy }\end{array}$ & $\begin{array}{l}\text { Light } \\
\text { microscopy }\end{array}$ & & & $\begin{array}{l}\text { Immul } \\
\text { rescen }\end{array}$ \\
\hline & Injury pattern & & $\begin{array}{l}\text { Electron dense } \\
\text { deposits }\end{array}$ & $\begin{array}{l}\text { The } \\
\text { percent of } \\
\text { infiltrate } \\
\text { CLL cells }\end{array}$ & $\begin{array}{l}\text { Proliferation } \\
\text { centers }\end{array}$ & Granulomatous & \\
\hline 1 & Membranous nephritis & $\begin{array}{l}\operatorname{lgG}++, \mathrm{C} 3+ \\
\mathrm{C} 1 \mathrm{q}+\end{array}$ & $\begin{array}{l}\text { Subepithelial } \\
\text { deposits }\end{array}$ & $10 \%$ & No & No & Negat \\
\hline 2 & Mininal change & Negative & No deposits & $90 \%$ & Yes & No & Negat \\
\hline 3 & $\begin{array}{l}\text { Focal mesangial and } \\
\text { endocapillary } \\
\text { proliferative } \\
\text { glomerulonephritis }\end{array}$ & $\mathrm{C} 3++$ & $\begin{array}{l}\text { Mesangial and } \\
\text { hump-like } \\
\text { subepithelial } \\
\text { deposits }\end{array}$ & $10 \%$ & No & No & Negat \\
\hline 4 & $\begin{array}{l}\text { Membranoproliferative } \\
\text { glomerulonephritis }\end{array}$ & $\operatorname{lgG}++, \operatorname{lgM}+++, \mathrm{C} 3+, \mathrm{C} 1 \mathrm{q}+, \mathrm{K}++, \lg \mathrm{G} 1++, \lg \mathrm{G} 2++$ & $\begin{array}{l}\text { Subendothelial } \\
\text { deposits with } \\
\text { microtubule } \\
\text { formation }\end{array}$ & $10 \%$ & No & No & Negat \\
\hline 5 & Mininal change & Negative & No deposits & $90 \%$ & Yes & Yes & Negat \\
\hline 6 & $\begin{array}{l}\text { Membranoproliferative } \\
\text { glomerulonephritis }\end{array}$ & $\begin{array}{l}\lg \mathrm{G}++, \mathrm{C} 3++, \mathrm{C} 1 \mathrm{q}+, \mathrm{K}++ \\
\lg \mathrm{G} 1++\end{array}$ & $\begin{array}{l}\text { Subendothelial } \\
\text { and } \\
\text { subepithelial } \\
\text { deposits with } \\
\text { microtubule } \\
\text { formation }\end{array}$ & $70 \%$ & Yes & No & $\begin{array}{l}\mathrm{K}++ \\
\lg \mathrm{g} 1+\end{array}$ \\
\hline 7 & $\begin{array}{l}\text { Focal mesangial and } \\
\text { endocapillary } \\
\text { proliferative } \\
\text { glomerulonephritis }\end{array}$ & C3++ & $\begin{array}{l}\text { Mesangial and } \\
\text { hump-like } \\
\text { subepithelial } \\
\text { deposits }\end{array}$ & $50 \%$ & Yes & No & Negat \\
\hline 8 & $\begin{array}{l}\text { Mesangial } \\
\text { proliferative } \\
\text { glomerulonephritis } \\
\text { and thrombotic } \\
\text { microangiopathy }\end{array}$ & $\mathrm{C} 3++$ & $\begin{array}{l}\text { Mesangial and } \\
\text { Subendothelial } \\
\text { deposits }\end{array}$ & $30 \%$ & Yes & No & Negat \\
\hline 9 & $\begin{array}{l}\text { Glomerular } \\
\text { hypertrophy }\end{array}$ & Negative & No deposits & $20 \%$ & No & No & Negat \\
\hline 10 & $\begin{array}{l}\text { Membranoproliferative } \\
\text { glomerulonephritis }\end{array}$ & $\operatorname{lgM}++, \mathrm{K}++$ & $\begin{array}{l}\text { Subendothelial } \\
\text { and mesangial } \\
\text { deposits with } \\
\text { microtubule } \\
\text { formation }\end{array}$ & $50 \%$ & Yes & No & $\begin{array}{l}\operatorname{lgM}++ \\
\mathrm{K}++\end{array}$ \\
\hline
\end{tabular}

\section{Figures}




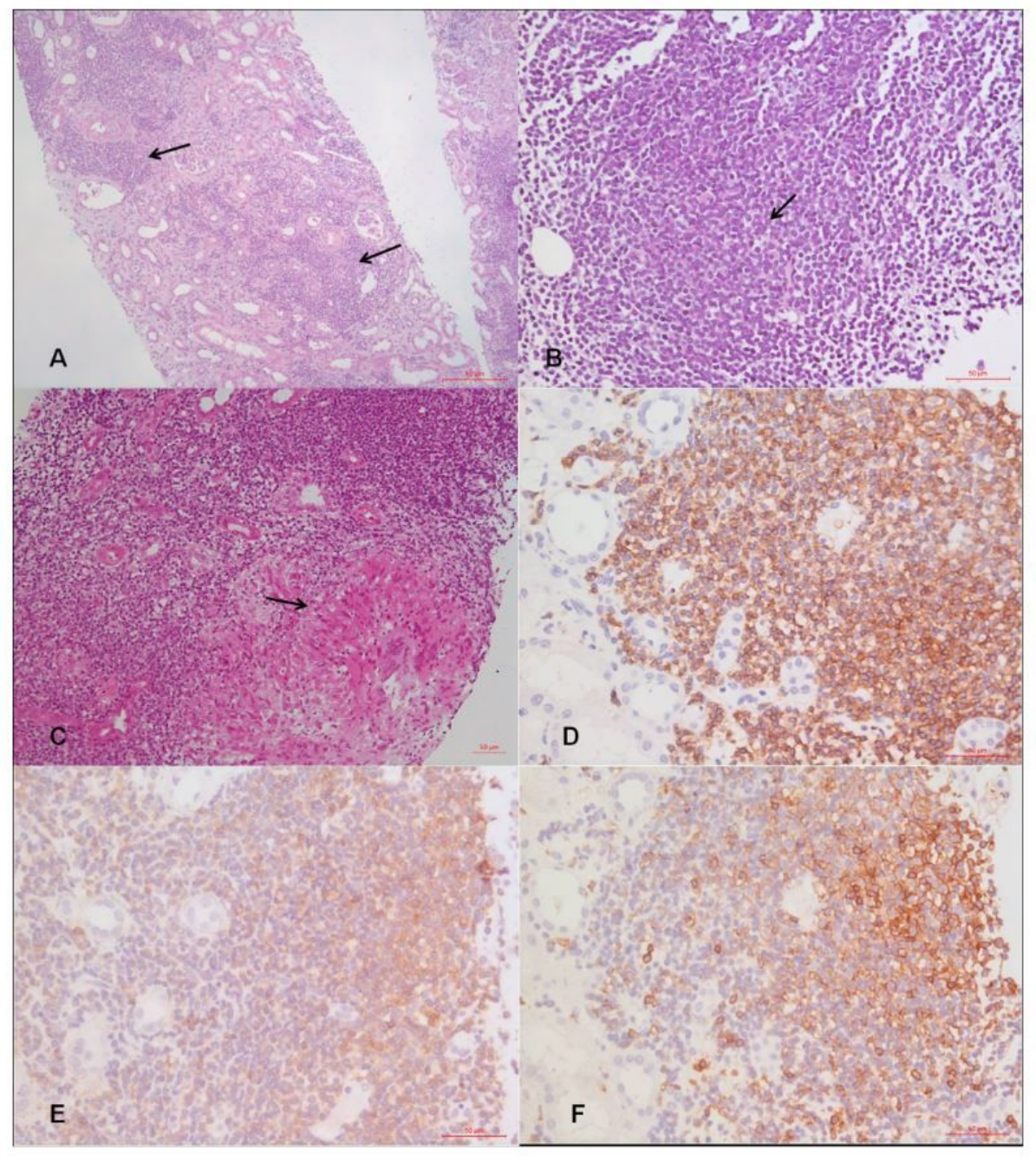

\section{Figure 1}

Representative light microscopic findings of renal biopsy. A. CLL cells infiltration was seen in renal interstitium as indicated by arrows (HE, $\times 100)$. B. Proliferation centers were detected in renal interstitium as indicated by the arrow $(\mathrm{HE}, \times 400)$. C. Interstitial gigantocellular granulomas were formed in renal interstitium as indicated by the arrow $(\mathrm{HE}, \times 200)$. D. Infiltrating CLL cells stain positively for CD20 (IHC, $\times 200)$. E. Infiltrating CLL cells stain positively for CD 5 (Immunohistochemistry, ×200). F. Infiltrating CLL cells stain positively for CD23 (Immunohistochemistry, $\times 200$ ). 


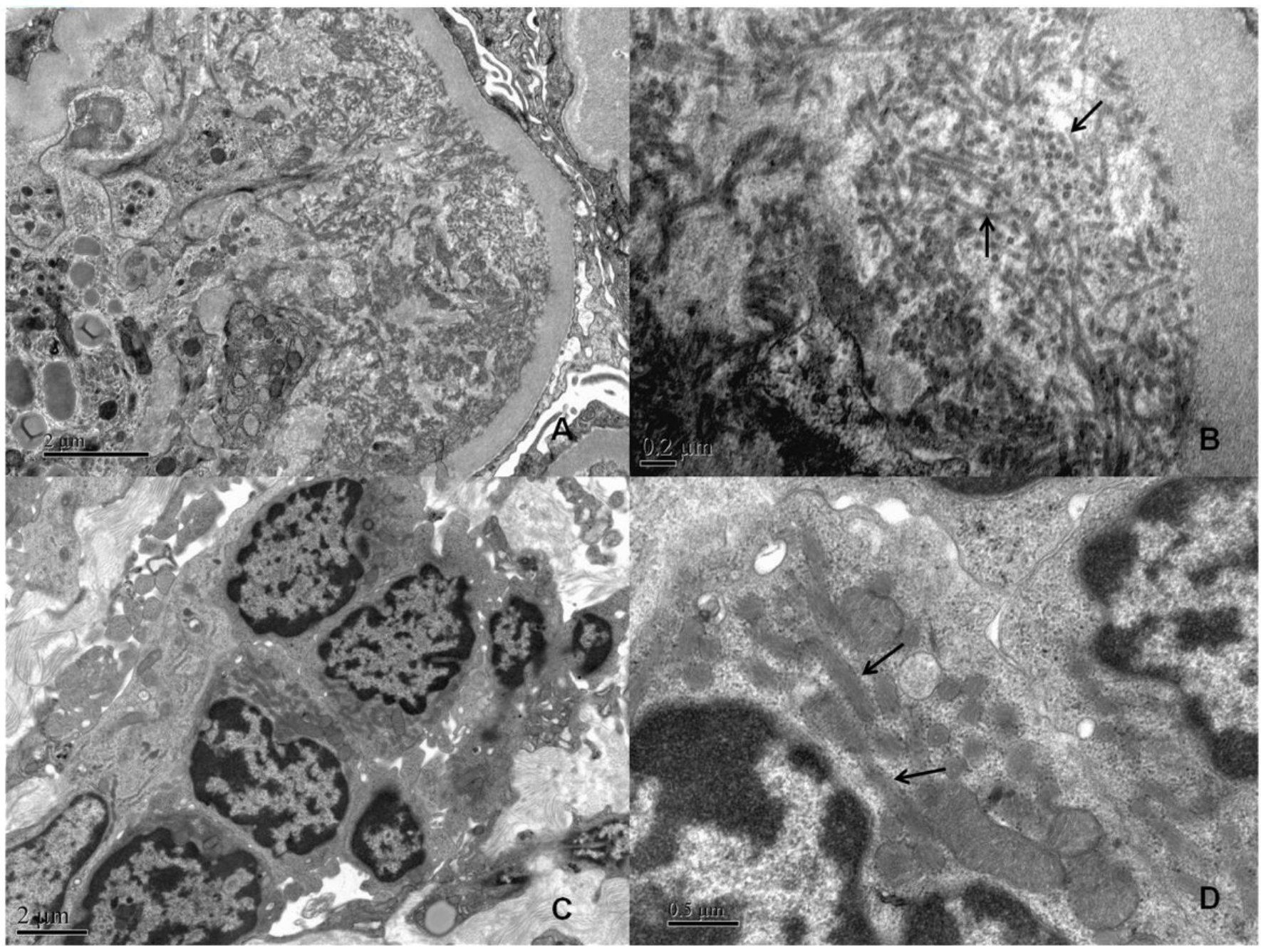

\section{Figure 2}

Representative electron microscopy findings of renal biopsy in case 6. A. Large subendothelial deposits characterized by microtubule formation were detected in glomeruli $(\times 15000)$. B. Enlargement of picture A showed 40-nm diameter microtubule formation as indicated by arrows ( $\times 50000)$. C.Neoplastic cells infiltration was seen in renal interstitium $(\times 10000)$. D. Special crystal structures characterized by fuzzy filament structure were found in infiltrating neoplastic cells as indicated by arrows $(\times 40000)$. 

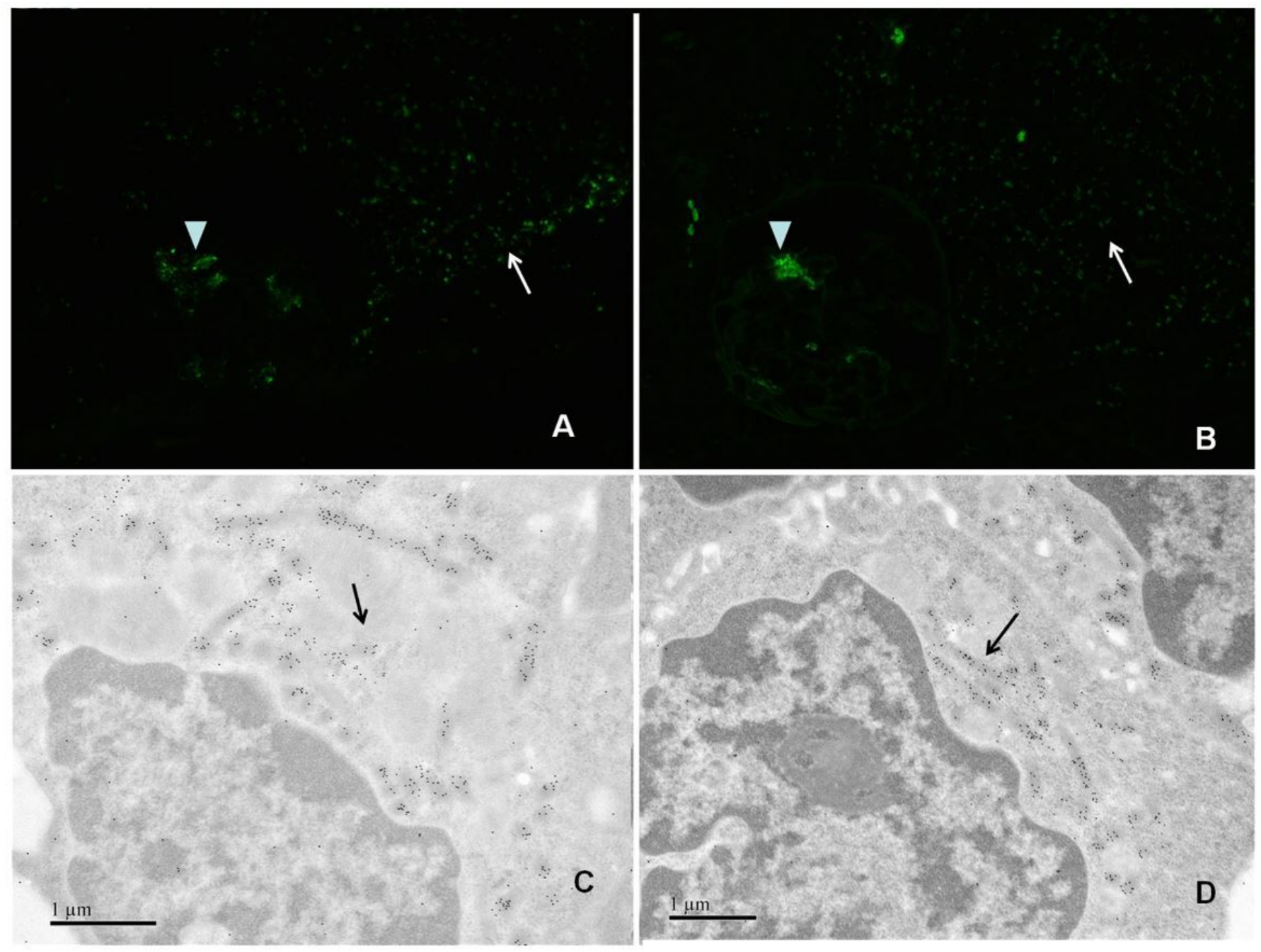

\section{Figure 3}

Representative immunohistochemistry findings of renal biopsy in case 6. A. Scattered granular staining of IgG1 was shown in the interstitium as indicated by the arrow with crumby staining in glomeruli indicated by the arrowhead (Immunofluorescence staining, $\times 200)$. B. Scattered granular staining of C3 was shown in the interstitium as indicated by the arrow with crumby staining in glomeruli indicated by the arrowhead (Immunofluorescence staining, $\times 200$ ). C. Intense IgG1 was detected in the crystal structures of neoplastic cells as indicated by the arrow. (Immunoelectron microscopy labelling, $\times 30000$ ). D. Intense C 3 was detected in the crystal structures of neoplastic cells as indicated by the arrow. (Immunoelectron microscopy labelling, $\times 25000$ ). 


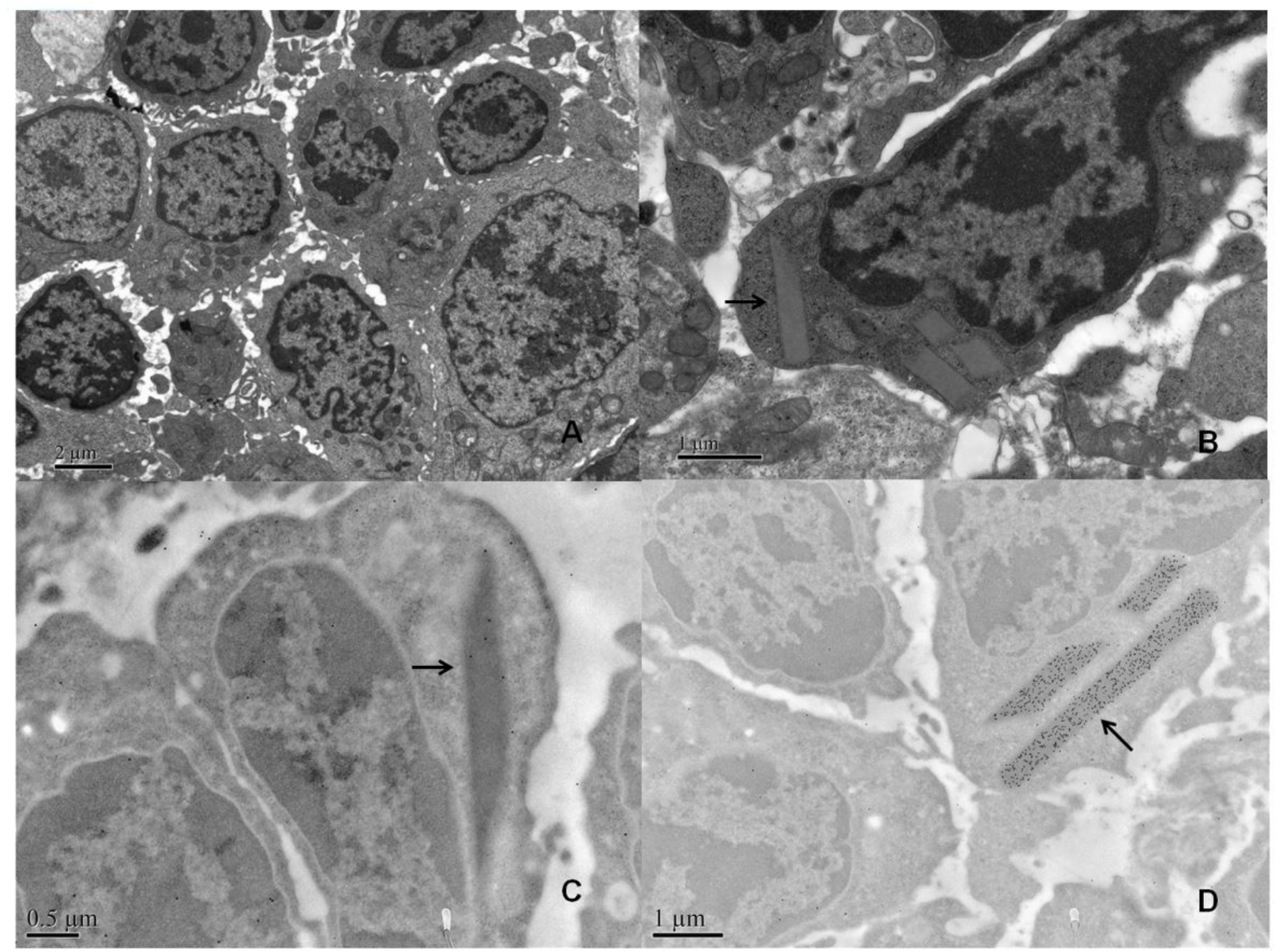

\section{Figure 4}

Representative electron microscopy findings of renal biopsy in case 2. A. Neoplastic cells infiltration was seen in renal interstitium ( $\times 8000)$. B. Rhombic crystals were formed in infiltrating neoplastic cells as indicated the arrow $(\times 25000)$. C. Light kappa was not detected in neoplastic cells. (Immunoelectron microscopy labelling, $\times 30000$ ). D. Intense light lamda was detected in the crystal structures of neoplastic cells as indicated by the arrow. (Immunoelectron microscopy labelling, $\times 20000$ ). 